INTIQAD: JURNAL AGAMA DAN PENDIDIKAN ISLAM

ISSN 1979-9950 (print) || ISSN 2598-0033 (online), http://jurnal.umsu.ac.id/index.php/intiqad DOI: 10.30596/intiqad.v12i2.4640

Vol. 12, No. 2 (December 2020)

\title{
Korelasi Kegiatan Ekstrakurikuler Sanggar Al-Quran dengan Hasil Belajar Al-Quran Hadits di MAN 4 Pasaman Barat
}

\author{
Nur Alim ${ }^{*}$, Mahyudin Ritonga ${ }^{2}$, Mafardi $^{3}$ \\ Universitas Muhammadiyah Sumatera Barat*1, 2,3 \\ *1email: mahyudinritonga@gmail.com
}

\begin{abstract}
This article aims to determine the correlation of the extracurricular activities of the al-Quran workshop with the results of learning the Qur'an hadith in MAN 4 Pasaman Barat, regency of West Pasaman. These types of research are quantitative descriptive and field research. Method of research that authors use the documentation of the value of subjects Qur'anic hadith. Secondary data source is, the value of the workshop obtained from the results of extracurricular activities of the Qur'an in MAN 4 Pasaman Barat, namely data obtained from the poll is poured in SPSS. The results showed that in MAN 4 Pasaman Barat, regency of West Pasaman, programmatic in the form of extracurricular activities of the Qur'anic religious workshop consisting of Tilawatil Qur'an, Fahmil Qur'an, Syahril Qur'an, Khottil Qur'an, Qur'anic poeisation, Nasheed. Results of analysis of the correlation between activities of the workshop al-Quran with the results of learning al-Quran Hadith is concluded that the extracurricular al-Quran workshop has a close relation with the results of learning al-Quran Hadith, the implications of this research is the need to increase extracurricular instensities in support of the intrurricular success.
\end{abstract}

Artikel Info

Keywords: Extracurricular, Al-Quran Gallery, Learning Outcomes, Correlation.

Received:

07 August 2020

Revised:

09 October 2020

Accepted:

10 November 2020

Published:

03 December 2020

\section{Abstrak}

Artikel ini bertujuan untuk mengetahui korelasi kegiatan ekstrakurikuler sanggar al-Qur'an dengan hasil belajar alQur'an Hadits di MAN 4 Pasaman Barat, Kabupaten Pasaman Barat. Jenis penelitian adalah penelitian lapangan (Field Research) yang bersifat deskriptif kuantitatif. Metode penelitian yang penulis gunakan dokumentasi nilai mata pelajaran al-Qur'an hadits. Sumber data sekunder adalah, 
nilai sanggar yang diperoleh dari hasil kegiatan ekstrakurikuler sanggar al-Qur'an di MAN 4 Pasaman Barat, yaitu data yang diperoleh dari angket dituangkan secara SPSS. Hasil penelitian menunjukkan bahwa di MAN 4 Pasaman Barat, Kabupaten Pasaman Barat, terprogram berupa kegiatan ekstrakurikuler sanggar al-Qur'an keagamaan yang terdiri dari Tilawatil Qur'an, Fahmil Qur'an, Syahril Qur'an, Khottil Qur'an, Puitisasi al-Qur'an, Nasyid. Hasil analisis terhadap korelasi antar kegiatan sanggar al-Quran dengan hasil belajar al-Quran Hadis dismpulkan bahwa ekstrakurikuler sanggar al-Quran memiliki keterkaitan yang erat dengan hasil belajar al-Quran Hadis, implikasi dari penelitian ini ialah perlunya peningkatan instensitas ekstrakurikuler guna mendukung kesuksesan intrakurikuler.

\section{Kata Kunci: Ekstrakurikuler, Sanggar Al-Qur'an, Hasil}

\section{Belajar, Korelasi.}

\section{A. Pendahuluan}

Al-Quran Hadis merupakan salah satu mata pelajaran bidang pendidikan agama Islam yang diajarkan di madrasah baik pada level Ibtidaiyah, Tsanawiyyah maupun Aliyah. Pelajaran al-Quran Hadis memiliki posisi penting dalam kaitannya dengan mata pelajaran pendidikan agam Islam lainnya seperti Fiqih, Aqidah Akhlak, Sejarah Kebudayaan Islam, karena al-Quran Hadis dapat secara langsung mendukung keberhasilan peserta didik pada mata pelajaran PAI lainnya.

Pernyataan di atas di dasarkan pada hasil penelitian para pemerhati pendidikan agama Islam, seperti
Musgamy yang menyimpulkan bahwa al-Quran Hadis mempengaruhi terhadap bahasa Arab (Awaliyah Musgamy, 2014), karena memudahkan peserta didik memahami makna serta pola-pola kalimat yang terdapat dalam bahasa Arab. Syaroji dalam analisis yang lebih luas juga menegaskan bahwa hadis mempengaruhi berbagai bidang kajian keislaman lainnya seperti fiqih, theologi (Syaroji Sy. 2017). Hidayat juga menegaskan bahwa kebiasaan membaca al-Quran memiliki hubungan dengan keterbentukan karakter siswa (Arif Hidayat, 2017). Karakter yang dalam bahasa pendidikan Islam lebih identik dengan akhlak juga merupakan sasaran 


\section{INTIQAD: JURNAL AGAMA DAN PENDIDIKAN ISLAM}

ISSN 1979-9950 (print) || ISSN 2598-0033 (online), http://jurnal.umsu.ac.id/index.php/intiqad

DOI: 10.30596/intiqad.v12i2.4640

Vol. 12, No. 2 (December 2020)

dari Pendidikan Agama Islam di madrasah.

Sejalan dengan urgensi mata pelajaran al-Quran Hadis terhadap mata pelajaran lain, Madrasah Aliyah Negeri 4 Pasaman Barat memiliki sebuah kegiatan ekstrakurikuler yang dikelola dalam bentuk sanggar oleh organisasi kesiswaan dengan bimbingan guru alQur'an Hadis. Keberadaan sanggar ini sebagaimana dikatakan oleh kepala sekolah untuk mendukung ketuntasan siswa pada berbagai bidang studi yang terkait dengan pendidikan agama Islam.

Al-Quran dan Hadis sebagai sumber ajaran Islam memiliki kontribusi yang nyata dan pengaruh yang besar terhadap pemahaman keislaman oleh setiap orang yang mempelajari ajaran agama Islam (Mahyudin Ritonya, et.al., 2020).

Sementara itu, keberhasilan dalam sebuah pembelajaran dapat diukur dari tiga aspek, yakni kognitif, afektif dan psikomotor (Durotul Yatimah, 2020), begitu juga dengan hasil belajar al-Quran dan Hadis di madrasah dapat dikategorikan sebagai pembelajaran yang berhasil harus mencapai batas atau ketuntasan minimal ketiga aspek yang disebutkan di atas.
Kegiatan ekstrakurikuler dalam berbagai bentuknya di setiap lembaga pendidikan memiliki tujuan yang berkaitan dengan penguatan kesuksesan peserta didik dalam mencapai tujuan pembelajaran yang setidaknya dalam level institusional. Dalam artian tidak ada ekstrakurikuler yang tidak mendukung intrakuruler.

Apresiasi yang perlu diberikan kepada MAN 4 Pasaman Barat ialah keberadaan sanggar al-Quran, ketika lembaga lain sibuk dengan ekstrakurikuler yang bersifat umum namun di sini malah dikembangkan ekstrakurikuler yang mengarah pada bidang keagamaan, keberadaan dan geliat sanggar al-Quran, rumah tahfiz, pondok al-Quran atau apalah namanya biasanya berada di luar lembaga pendidikan, namun MAN 4 Pasaman justru membinananya dengan membangun sanggar al-Quran.

Sanggar al-Quran sebagai wadah bagi siswa di MAN 4 Pasaman Barat juga memiliki tujuan yang mendukung pelaksanaan tujuan pembelajaran intrakurikuler dalam hal ini mata pelajaran al-Quran Hadis.

Mempelajari al-Quran dengan berbagai aspeknya adalah kewajiban 


\section{INTIQAD: JURNAL AGAMA DAN PENDIDIKAN ISLAM}

ISSN 1979-9950 (print) || ISSN 2598-0033 (online), http://jurnal.umsu.ac.id/index.php/intiqad

DOI: 10.30596/intiqad.v12i2.4640

Vol. 12, No. 2 (December 2020)

bagi setiap muslim. Kesibukan aktifitas di luar, tidak jarang membuat orang muslim belum bisa membagi waktunya secara efektif untuk mempelajari alQuran. Apalagi peserta didik, ketika sudah pulang dari sekolah maka yang terpikir adalah bermain dengan temanteman di sekitar rumah.

Sejalan dengan pendapat para ahli dan fakta di lapangan, penelitian ini bertujuan untuk mendeskripsikan korelasi kegiatan yang terdapat di sanggar al-Quran dengan hasil belajar alQuran Hadis, korelasi tersebut akan dilihat dari tiga ranah yakni kognitif, afektif dan psikomotor.

\section{B. Metode Penelitian}

Penelitian ini adalah bagian dari jenis penelitian kuantitatif yaitu penelitian korelasional (Indra Jaya, 2010). Sumber data penelitian adalah siswa MAN 4 Pasaman Barat, sumber skunder berupa dokumen kegiatan ekstrakurikuler yang terdapat di sanggar al-Quran MAN 4 Pasaman Barat.

Teknik pengumpulan data yang digunakan adalah penyebaran angket kepada siswa tentang kegiatan ekstrakurikuler yang mereka dapatkan di sanggar al-Quran baik dalam ranah kognitif, afektif, maupun psikomotor. Sementara data yang terkait dengan hasil belajar al-Quran Hadis didapat dari nilai laporan yang dimiliki oleh siswa pada semester ganjil tahun pelajaran 2019/2020.

Angket yang terkaait dengan kegiatan di sanggar al-Quran disusun dengan menggunakan Skala Likert dalam alternatif jawaban dan untuk masing-masing variable akan diberi skor sebagai berikut: Selalu, sering, kadangkadang, pernah, tidak pernah. Sedangkan dalam kisaran secara kontinu 1-5 dengan alternatif jawaban sebagai berikut: 1) Untuk siswa yang mengikuti kegiatan ekstrakurikuler sanggar al-Qur'an diberi skor $5=$ sangat tinggi, $4=$ tinggi, $3=$ cukup, 2 = rendah, 1 = sangat rendah. Sedangkan untuk hasil belajar siswa mengunakan analisis dokumen yang didapat dari guru mata pelajaran alQuran hadis diberi skor: 5 = sangat baik, 4 = baik, 3 = Cukup baik, 2 = kurang baik 1 = sangat tidak baik.

Adapun teknik analisis data yang digunakan dalam penelitian ini ialah uji korelasi personal, karena variabel $\mathrm{Y}$ dalam penelitian hanya satu sementara Variabel $\mathrm{X}$ terdapat tiga maka rumus 


\section{INTIQAD: JURNAL AGAMA DAN PENDIDIKAN ISLAM}

ISSN 1979-9950 (print) || ISSN 2598-0033 (online), http://jurnal.umsu.ac.id/index.php/intiqad

DOI: 10.30596/intiqad.v12i2.4640

Vol. 12, No. 2 (December 2020)

yang digunakan ialah sebagaimana gambar 1 di bawah ini:

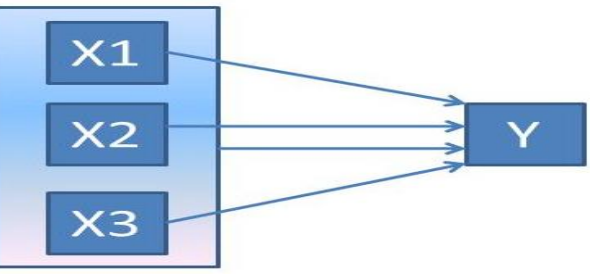

Gambar 1. Uji korelasi Personal

\section{Hasil Penelitian Dan Pembahasan}

Analisis deskriptif kegiatan ekstrakurikuler sanggar al-Quran aspek kognitif responden penelitian, diperoleh rerata hitung $($ mean $)=40.18$, standar deviasi $=3.54$, nilai minimum $=30$ dan maksimum $=44$. Selanjutnya distribusi frekuensi data kegiatan ekstrakurikuler sanggar al-Quran aspek kognitif dapat dikembangkan dalam tabel di bawah ini :

\section{Tabel 1. Data Kegiatan Ekstrakurikuler Sanggar al-Quran Aspek Kognitif}

\begin{tabular}{|c|c|c|}
\hline Rentang & FA & FR (\%) \\
\hline $30-32$ & 1 & 2.94 \\
\hline $33-35$ & 3 & 8.82 \\
\hline $36-38$ & 4 & 11.76 \\
\hline $39-41$ & 12 & 35.29 \\
\hline $42-44$ & 14 & 41.18 \\
\hline$\Sigma$ & 34 & 100 \\
\hline
\end{tabular}

Data di atas dapat diperjelas secara kuantitatif sebagaimana dalam gambar 2 di bawah ini:

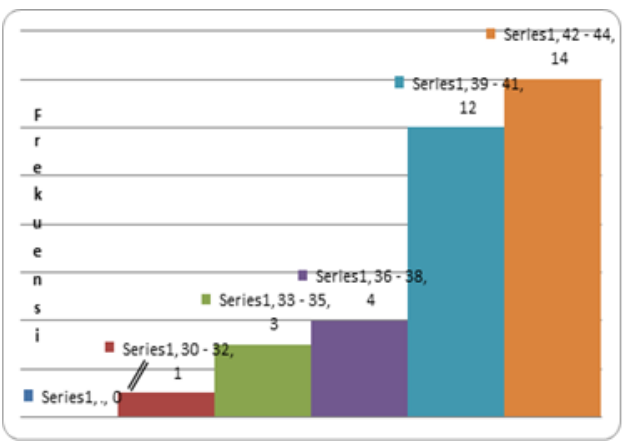

Gambar 2. Histogram Data Kegiatan Ekstrakurikuler Sanggar Al-Quran Aspek Kognitif

Berdasarkan tabel dan histogram di atas terlihat kegiatan ekstrakurikuler sanggar al-Quran aspek kognitif dari 34 orang sampel siswa MAN 4 Pasaman Barat sebanyak 1 orang responden berada dalam kelas interval 30-32, 3 orang berada dalam interval 33-35, 4 orang berada dalam interval 36-38, 12 orang berada dalam interval 39-41 dan 14 orang responden berada dalam interval 42-44.

Selanjutnya pada data di bawah ini akan dideskripsikan data yang berkaitan dengan kegiatan ekstrakurikuler sanggar alQuran dalam aspek afektif.

Analisis deskriptif kegiatan ekstrakurikuler sanggar al-Quran aspek afektif responden penelitian, diperoleh rerata hitung $($ mean $)=39.12$, standar 


\section{INTIQAD: JURNAL AGAMA DAN PENDIDIKAN ISLAM}

ISSN 1979-9950 (print) || ISSN 2598-0033 (online), http://jurnal.umsu.ac.id/index.php/intiqad DOI: 10.30596/intiqad.v12i2.4640

Vol. 12, No. 2 (December 2020)

deviasi $=3.28$, nilai minimum $=30$ dan maksimum $=43$. Selanjutnya distribusi frekuensi data kegiatan ekstrakurikuler sanggar Al-Quran aspek afektif dapat disajikan pada tabel di bawah ini:

Tabel 2. Data Kegiatan Ekstrakurikuler Sanggar al-Quran Aspek Afektif

\begin{tabular}{|c|c|c|}
\hline Rentang & FA & FR (\%) \\
\hline $30-32$ & 2 & 5.88 \\
\hline $33-35$ & 1 & 2.94 \\
\hline $36-38$ & 11 & 32.35 \\
\hline $39-41$ & 9 & 26.47 \\
\hline $42-44$ & 11 & 32.35 \\
\hline$\sum$ & 34 & 100 \\
\hline
\end{tabular}

Data di atas ketika dikonversikan pada bentuk histogram maka dapat terlihat sebagaimana gambar 3 di bawah ini:

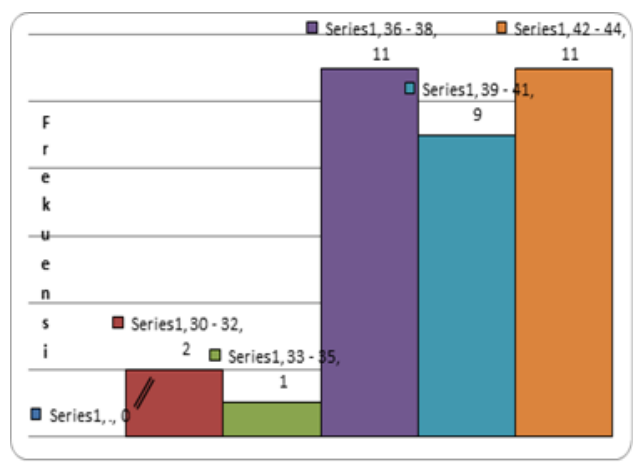

Gambar 3. Histogram Data Kegiatan Ekstrakurikuler Sanggar Al-Quran Aspek Afektif

Berdasarkan tabel dan histogram di atas terlihat kegiatan ekstrakurikuler sanggar al-Quran aspek afektif dari 34 orang sampel siswa MAN 4 Pasaman Barat sebanyak 2 orang responden berada dalam kelas interval 30-32, 1 orang berada dalam interval 33-35, 11 orang berada dalam interval 36-37, 9 orang berada dalam interval 39-41 dan 11 orang responden berada dalam interval 42-44.

Selanjutnya data yang terkait dengan kegiatan sanggar al-Quran pada aspek psikomotor akan dijelaskan di pada penjelasan selanjutnya.

Analisis deskriptif kegiatan ekstrakurikuler sanggar al-Quran aspek psikomotor responden penelitian, diperoleh rerata hitung (mean) $=18.62$, standar deviasi $=3.09$, nilai minimum $=14$ dan maksimum $=25$. Selanjutnya distribusi frekuensi data kegiatan ekstrakurikuler sanggar al-Quran aspek psikomotor sebagai berikut:

Tabel 3. Data Kegiatan Ekstrakurikuler Sanggar al-Quran Aspek Psikomotor

\begin{tabular}{|c|c|c|}
\hline Rentang & FA & FR (\%) \\
\hline $13-15$ & 4 & 11.76 \\
\hline $16-18$ & 17 & 50.00 \\
\hline $19-21$ & 7 & 20.59 \\
\hline $22-24$ & 3 & 8.82 \\
\hline $25-27$ & 3 & 8.82 \\
\hline$\sum$ & 34 & 100 \\
\hline
\end{tabular}




\section{INTIQAD: JURNAL AGAMA DAN PENDIDIKAN ISLAM}

ISSN 1979-9950 (print) || ISSN 2598-0033 (online), http://jurnal.umsu.ac.id/index.php/intiqad DOI: 10.30596/intiqad.v12i2.4640

Vol. 12, No. 2 (December 2020)

Data sebagaimana terdapat tabel 3 di atas dapat digambarkan dalam bentuk histogram sebagaimana pada gambar 4 berikut ini:

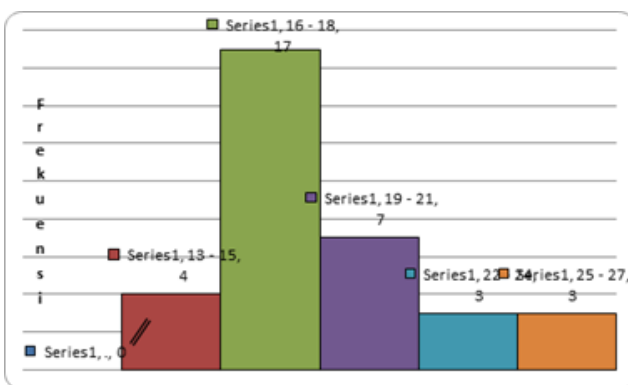

Gambar 4. Histogram Data Kegiatan Ekstrakurikuler Sanggar al-Quran Aspek Psikomotor

Berdasarkan tabel dan histogram di atas terlihat kegiatan ekstrakurikuler sanggar al-Quran aspek psikomotor dari 34 orang sampel siswa MAN 4 Pasaman Barat sebanyak 4 orang responden berada dalam kelas rentang 13-15, 17 orang berada dalam interval 16-18, 7 orang berada dalam rentang 19-21, 3 orang berada dalam rentang 22-24 dan 3 orang responden berada dalam rentang 25-27.

Selanjutnya akan dideskripsikan data yang terkait dengan hasil belajar al-Quran Hadis.

Analisis deskriptif hasil belajar alQuran hadits responden penelitian, diperoleh rerata hitung (mean) $=87.41$, standar deviasi $=6.19$, nilai minimum $=$ 70 dan maksimum $=96$. Selanjutnya distribusi frekuensi data hasil belajar AlQuran Hadits sebagai berikut:

Tabel 4. Data Hasil Belajar al-Quran Hadis

\begin{tabular}{|c|c|c|}
\hline Rentang & FA & FR (\%) \\
\hline $70-75$ & 1 & 2.94 \\
\hline $76-81$ & 5 & 14.71 \\
\hline $82-87$ & 7 & 20.59 \\
\hline $88-93$ & 15 & 44.12 \\
\hline $94-99$ & 6 & 17.65 \\
\hline$\sum$ & 34 & 100 \\
\hline
\end{tabular}

Hasil belajar al-Quran dan Hadits sebagaimana pada tabel 4 di atas dapat diperjelas dengan histogram sebagaimana pada gambar 5 di bawah ini:

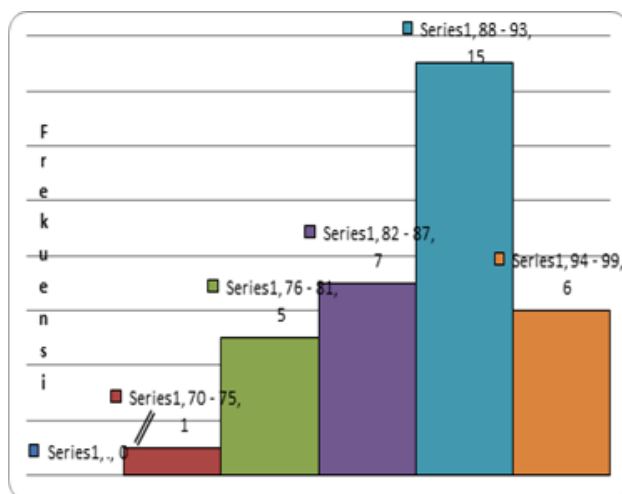

Gambar 5. Histogram Data Hasil Belajar Al-Quran Hadits 
ISSN 1979-9950 (print) || ISSN 2598-0033 (online), http://jurnal.umsu.ac.id/index.php/intiqad

DOI: 10.30596/intiqad.v12i2.4640

Vol. 12, No. 2 (December 2020)

Berdasarkan tabel dan histogram di atas terlihat hasil belajar al-Quran hadits dari 34 orang sampel siswa MAN 4 Pasaman Barat, 1 orang responden berada dalam kelas interval 70-75, 5 orang berada dalam interval $76-81,7$ orang dalam interval 82-87, 15 orang berada dalam interval 88-93 dan 6 orang responden berada dalam interval 94-99.

Setelah dilakukan uji korelasional maka hasil analisis menunjukkan bahwa kegiatan ekstrakurikuler sanggar alQuran aspek kognitif $\left(\mathrm{X}_{1}\right)$ dengan hasil belajar al-Quran Hadits (Y) terdapat hubungan yang signifikan serta memberikan kontribusi yang berarti terhadap hasil belajar al-Quran Hadits.

Hasil analisis menunjukkan bahwa kegiatan ekstrakurikuler sanggar alQuran aspek apektif $\left(\mathrm{X}_{2}\right)$ dengan hasil belajar al-Quran Hadits (Y) terdapat hubungan yang signifikan serta memberikan kontribusi yang berarti terhadap hasil belajar al-Quran Hadits.

Hasil analisis menunjukkan bahwa kegiatan ekstrakurikuler sanggar alQuran aspek psikomotor $\left(\mathrm{X}_{3}\right)$ dengan hasil belajar al-Quran Hadits (Y) terdapat hubungan yang signifikan serta memberikan kontribusi yang berarti terhadap hasil belajar al-Quran Hadits.
Berdasarkan fakta, penulis mendapatkan data analisis dengan kenyataan di lapangan memang cocok. Terlihat adanya kesesuaian antara data dan fakta yang telah terjadi. Dengan kata lain, bahwa penelitian ini menunjukkan hasil yang sesuai dengan prosedur dan hasilnya.

Hasil penelitian ini menunjukkan adanya relevansi dengan hasil penelitian yang dilakukan oleh Ruqaiyah dkk yang mengatakan bahwa motivasi belajar dan kegiatan ekstrakurikuler sanggar alQuran mempengaruhi prestasi belajar siswa (Anis Ruqaiyah, 2017).

Pada sisi lain penelitian ini juga mendukung kesimpulan Adiwijayanti dkk yang mengatakan bahwa hafalan alQuran memberikan pengaruh yang besar terhadap hasil belajar matematika (Adiwijayanti, 2019), keterkaitan hasil penelitian ini dengan penelitian yang dilakukan oleh Adiwijayanti ialah berada pada hafalan al-Quran, karena salah satu program yang ada di sanggar al-Quran MAN 4 Pasaman Barat ialah tahfiz alQur'an.

Hasil penelitian ini juga mendukung hasil penelitian yang dilakukan oleh Nofianti yang mengatakan bahwa ekstrakurikuler 
mempengaruhi motivasi dan hasil belajar siswa (Ani Nofianti, 2018).

Inriyani dkk. (2017), juga menyimpulkan bahwa ekstrakurikuler mempengaruhi hasil belajar peserta didik. Beberapa penelitian di atas menjadi dasar bagi peneliti untuk mengungkapkan suatu temuan penelitian bahwa ekstrakurikuler yang dikelola secara terstruktur dan terarah tidak akan pernah menyita waktu belajar siswa, bahkan dengan ekstrakurikuler tersebut ketuntasan siswa dalam belajar akan semakin mudah untuk dicapai, oleh karenanya ekstrakurikuler pada setiap mata pelajaran perlu dipikirkan bersama oleh guru mata pelajaran dan wakil kepala bidang kurikulum.

\section{Kesimpulan}

Berdasarkan hasil analisis tehadap penelitian yang dilakukan dapat ditarik kesimpulan bahwa ekstrakurikuler sanggar al-Quran memberikan kontribusi dalam meningkatkan hasil belajar siswa pada mata pelajaran al-Quran dan Hadis, kontribusi itu terlihat pada aspek kognitif, afektif dan psikomotorik.

Implikasi dari penelitian ini ialah kerjasama antar guru al-Quran Hadis dengan wakil kepala bidang kesiswaan perlu ditingkatkan karena masih banyak di antara siswa yang tidak mau ikut dalam kegiatan ekstrakurikuler di sanggar al-Quran.

Di samping itu, wakil kepala bidang kurikulum juga perlu untuk memikirkan bagaimana bentuk ekstrakurikuler yang akan dikembangkan guna mendukung intrakurikuler bidang studi lain, sehingga semua intrakurikuler didukung dengan ekstrakurikuler yang relevan.

\section{E. Daftar Pustaka}

Adiwijayanti, Dewi Dwi. Purwati, Heni. Sugiyanti. (2019). 'Pengaruh Hafalan Al-Qur'an Terhadap Prestasi Belajar Matematika Siswa MTs'. SQUARE: Journal of Mathematics and Mathematics Education, 1 (2), 109-16.

Hidayat, Muhammad Arif. (2017). 'Hubungan Kebiasaan Membaca Al-Qur'an Dengaan Pembentukan Karakter Agama Islam Siswa Kelas XI MAN 2 Model Medan'. Intiqad Jurnal Agama dan Pendidikan Islam, 9 (2), 52-62

Inriyani, Yayan. Wahjoedi. Sudarmiatin. (2017). 'Pengaruh Kegiatan 


\section{INTIQAD: JURNAL AGAMA DAN PENDIDIKAN ISLAM}

ISSN 1979-9950 (print) || ISSN 2598-0033 (online), http://jurnal.umsu.ac.id/index.php/intiqad DOI: 10.30596/intiqad.v12i2.4640

Vol. 12, No. 2 (December 2020)

Ekstrakurikuler Terhadap Prestasi Belajar IPS Melalui Motivasi Belajar'. Jurnal Pendidikan: Teori, Penelitian, dan Pengembangan, 2 (7), 955-62

Jaya, Indra. (2010). Statistik Penelitian Untuk Pendidikan. Bandung: Citapustaka Media Perintis.

Musgamy, Awaliyah. (2014). 'Pengaruh Al-Quran Hadis Terhadap Bahasa Arab'. Jurnal Al Hikmah, XV (2), $35-43$

Nofianti, Ani. (2018). 'Pengaruh Kegiatan Ekstrakurikuler dan Motivasi Belajar Terhadap Prestasi Belajar Siswa'. Jurnal Dinamika Manajemen Pendidikan, 2 (2), 120-29

Ritonga, Mahyudin. Bustami, Hafni. Saputra, Riki. Hakim, Rosniati. Mursal, Elhusen, Shofwan Karim. (2020), 'Reformulating the Arabic Language Teaching Materials Within the Framework of Generating New Cadres of Tarjih and Tajdid Ulama Islamic Law Study Program Faculty of Islamic Religion, Muhammadiyah University of', International Journal of Advanced Science and
Technology, 29 (7), 185-90

Ruqaiyah, Anis. Bolotio, Rivai. Ardianto. (2017). 'Pengaruh Motivasi Belajar Dan Kegiatan Ekstrakurikuler Sanggar Alquran Terhadap Prestasi Belajar Siswa Pada Mata Pelajaran Alquran Hadis di Madrasah Aliyah Di Kota Manado'. Journal of Islamic Education Policy, 2 (2), 123-39

Sy, Syaroji. (2017). 'Pengaruh Hadis Dalam Ilmu Fiqih Dan Teologi (Kajian Tokoh Dan Pemikiran Imam Syafii)'. AL-FURQANIA, 5 (2), 221-33

Yatimah, Durotul. (2020). 'Implementation of Psychomor Assessment on Life Skills Learning Program Package'. Humanities \& Social Sciences Reviewers, 8 (1), 171-76 